\title{
Developing cheese tourism: a local-based perspective from Valle de Roncal (Navarra, Spain)
}

\author{
Francesc Fusté-Forné (D)
}

\begin{abstract}
This paper aims to investigate the opinions of local cheese producers with regard to the relationships between cheese and tourism in rural areas. Based on a case study approach, data was collected through semi-structured interviews with cheesemakers and visits to cheesemaking facilities in Valle de Roncal (Roncal valley), a mountain region in northern Spain. Results of this research show that cheese producers in rural areas award tourism value to cheese by appreciating its historical linkages to land and landscapes, the rural lifestyle, and a regional communication of cheese. The originality of this paper lies on the approach to a niche tourism which is drawn from the understanding of cheese as both a local product and a tourist attraction, from the perspective of local producers in peripheries. This research informs rural tourism planners in the design of (food) tourist experiences that rely on a local-based storytelling.
\end{abstract}

Keywords: Culinary heritage, Food narrative, Gastronomy, Pyrenees, Rural tourism, Sustainable development

\section{Introduction}

Cheese tourism is a niche food tourism which in recent years has witnessed an increasing research interest by academics worldwide [1]. Cheese landscapes are a symbol of rural identity and a factor of tourist attraction [2]. Food tourism refers to the visit to a destination in order to discover the idiosyncrasies of its culture and nature through its culinary heritages [3]. In particular, peripheries like rural, natural, and mountain environments emerge as repositories of old traditions which are still being preserved and communicated. In focusing on cheese tourism, this type of specialist tourism specifically reflects a relationship between cheese and tourism that acknowledges the process of awarding tourism value to a local dairy product [4].

Spain is one of the most important European and worldwide cheese regions-it counts on twenty-eight

Correspondence: researchexperiencetourism@gmail.com;

francesc.fusteforne@udg.edu

Department of Business, Faculty of Tourism, University of Girona, Plaça Josep Ferrater i Móra, 1, 17004 Girona, Catalonia, Spain milk and cheese production regions acknowledged as protected designation of origin (PDO) or protected geographical indication (IGP) [5]. Dairy and cheese production are critical industries in Spanish economy [6], and cheese is a cultural and natural identity factor in areas such as the Pyrenees ranges [7]. In this context, the paper investigates the state of cheese tourism development in Valle de Roncal-Roncal valley-(Navarra, Spain) with the aim to identify the opportunities and challenges derived from cheese tourism. Roncal valley counts on the oldest protected designation of origin (PDO) in Spain, awarded to Roncal cheese in 1981, acknowledging the valley as a quality environmental area with a cultural and historical tradition in cheese production. Roncal cheese is both an example of a tourist attraction and a manifestation of ethnic identity [8]. However, no previous research has analyzed Roncal cheese from the perspective of tourism development.

In order to approach the topic, this research is drawn from the perspective of local cheesemakers. The study method is based on a qualitative study which relies on

(c) The Author(s). 2020 Open Access This article is licensed under a Creative Commons Attribution 4.0 International License, which permits use, sharing, adaptation, distribution and reproduction in any medium or format, as long as you give appropriate credit to the original author(s) and the source, provide a link to the Creative Commons licence, and indicate if changes were made. The images or other third party material in this article are included in the article's Creative Commons licence, unless indicated otherwise in a credit line to the material. If material is not included in the article's Creative Commons licence and your intended use is not permitted by statutory regulation or exceeds the permitted use, you will need to obtain permission directly from the copyright holder. To view a copy of this licence, visit http://creativecommons.org/licenses/by/4.0/. 
semi-structured interviews and on-site visits to cheese facilities. Among the key themes pointed by the cheesemakers with regard to the relationship between "cheese" and "tourism," they underlined the inherent difficulty of rural life and the seasonality of tourist demand as examples of the challenges they are currently facing. On the other side, results demonstrate that both Roncal's sense of place and the added value of a quality cheese (with a protected designation of origin certification) provide great opportunities to develop a cheese tourism offer and foster its economic benefits. Thus, this study contributes to the understanding of the processes of attributing tourism value to cheese in the region of Roncal, from a producers' perspective.

This paper is structured into four parts. After the "Introduction" section, the paper analyzes the development of cheese tourism within the framework of the relationships between food and tourism. Later, the study method is described and the results are presented. Finally, the "Discussion and conclusions" section outlines both the contribution of this research, its limitations, together with opportunities for future research.

\section{The development of cheese tourism in peripheries}

This section reviews the importance of food tourism for destination development, and specifically, it focuses on the role of cheese tourism as a niche tourism within the growing appeal of gastronomy as a motivation factor for tourists.

\section{Food and tourism - a main course in rural environments}

Recent research has analyzed food tourism terminologies [9], and one of the most accepted definitions is still the food tourism concept defined by Hall and Sharples [10], who stated that food tourism refers to the journey to gastronomic regions, with recreational and entertainment purposes, which includes visits to food producers, gastronomic festivals and food fairs, events, farmers' markets, cooking shows and demonstrations, tasting food products, or other food-based tourist activities. Thus, among the different possibilities offered by food tourism practices and experiences, the UNWTO [3] affirms that "over recent decades, gastronomy tourism has gone beyond the table setting and now includes all sectors of a destination's food and tourism chain-producers (agriculture, fishing, etc.), processing firms (dairies, olive mills, canning plants, wineries, etc.), the tourism and hospitality sector (restaurants, specialised accommodation, gastronomic activity firms, etc.), the retail sector, the commerce sector (sale of products) and even the knowledge sector".

In particular, food tourism refers to the discovery of a culture through its food [11]. In this sense, "gastronomy tourism is therefore based on a concept of knowing and learning, eating, tasting and enjoying the gastronomic culture that is identified with a territory. [...] The territory is the backbone of gastronomy because a destination's landscapes, culture, products, techniques and dishes define its culinary identity and are the foundation of, and should be part of, the DNA of the tourism experiences offered to visitors" [3]. As a significant ingredient of tourist destinations, food tourism is growing rapidly. For example, the Spanish case shows that $15 \%$ of tourists arriving to Spain are motivated by its gastronomy, with an estimate budget which is $20 \%$ higher than average tourists [12].

In rural and mountain destinations, the relationships between tourism and primary activities cannot be only examined by considering the number of visitors or their expenditure, and tourism planning and development needs to take into account the perspectives of rural entrepreneurs-namely, local cheesemakers-in order to know first-hand how they perceive the relationship between agriculture and tourism. For example, adjusting schedules and activities to the needs of visitors may imply a loss of the authenticity of traditional agricultural activities $[2,4]$. This has been scarcely studied in previous research, and it represents one of the gaps this paper aims to fill in. Agriculture, livestock, and fishing activities are the starting point of food tourism, because "agriculture provides the product; culture provides the authenticity; and tourism provides the infrastructure and services" [13]. Within this context, food is taking an increasing role as a tourist attraction and a motivation factor [14]. Here, according to Miele and Murdoch, "the practical aesthetic of typical foods is founded on the linkage between food and terroir. This linkage is important in defining the quality of the food [...]. The specific taste of typical foods is constructed through their association with the landscape of production, as though the soil can somehow be savoured in the food" [15].

Previous research also acknowledged that both local food producers and restaurants with a pride of the land are crucial to design a genuine food tourist experience [16]. Germann Molz affirms that "in the stories roundthe-world travelers recount, it is clear that food is seen as symbolic of particular places and as a way of getting close to or consuming the essence of those places" [17]. This authenticity, or uniqueness, can be understood as the combination of "historical memory, geographic localisation, quality of raw materials and techniques of preparation" ([18] cited by 15). In the framework of narratives built around local produce, representatives of host communities are the most significant actors, as Walsh et al. [19] state, "who is more credible than the residents of the host community?" This paper particularly approaches the process of awarding tourism value to cheese from the perspective of local cheesemakers.

\section{Cheese tourism-a growing tasting journey}

Cheese-oriented tourism is based on the interest towards the development of a product that is closely linked to 
the territory [4]. Cheese is made from milk obtained from the animals which graze and feed on the own land, showing a process that keeps the authenticity from land to table-where cheesemakers are gatekeepers of this unique heritage. Previous studies acknowledged that visitors and tourists like to buy at the source of the product, that is, people like to buy "cheese" where this is made and from the hands of people who makes it [20]. Cheese tourism involves the visit to areas of cheesemaking and milk production, which means that this special interest tourism is primarily practiced in rural, mountain, and natural areas. Cheese-based tourism practices and experiences do not only include cheese tastings, but also a range of synergies focused on food consumption that encompass food tours and festivals, and visits to local markets, all of them emerging as pathways for the promotion and selling of cheese. There are many examples around the world which suggest the significance of cheese as a tourism attraction and a motivation factor, such as the Camembert village in France, the Gouda Cheese Market in The Netherlands, or the Wisconsin Cheese Trails in the USA, to cite some of them.

With regard to the Spanish case, Spain is a country with a long tradition in milk production and cheesemaking. This is exemplified with the quality labeling of twentyeight milk and cheese production areas as protected designation of origin (PDO)-twenty-six of them-and protected geographical indication (IGP) - two of them. According to previous research, "the quality label of Protected Designation of Origin gives to the production area a high visibility that benefits not only selling the product but also its conversion into a tourist resource with respect to cheese as a product, and the region as a destination" [2]. There are some examples of previous researches that elevate cheese from a food product, to the status of a tourist product. In this sense, although cheese tourism as a specific type of tourism is still an emerging field of research, there is a growing trend where "cheese tourism creates new destinations and contributes to existing destination branding" [1]. This is the case of studies which have focused on different destinations in Belgium [21], Brazil [22], Canada [23], Costa Rica [24], France [25], Italy [26], Mexico [27], New Zealand [28], Norway [29], Russia [1], and Spain [4, 30].

Spain occupies most of the Iberian Peninsula, in the southwest side of Europe. The tradition of cheesemaking in Spain is documented in the first medieval cookbooks in Catalan and Spanish languages which already included recipes with cheese, such as Llibre de Sent Soví, originally published in the fourteenth century [31]. While the Iberian Peninsula agglutinates very diverse geographical context in terms of climate and precipitation, or vegetation, cheese production is widely spread throughout the territory [5], with extensive possibilities for the development of the relationships between "cheese" and "tourism" [7]. As Michelson [32] states, cows are primarily found in coastal regions and northern and western valleys, while dairy produce in mountain areas predominantly depends on goats and sheep. In this sense, while artisan cheeses from northern regions offer a greater variety of textures and styles, more arid and mountainous areas in Western Spain, and regions such as the Canary Islands, produce cheeses with stronger flavors and, sometimes, spicy.

Cheeses reflect the environment and the land where they are produced, and its culinary culture. This is even more relevant in mountain territories, where the largest number of PDO cheeses in Spain is produced. For example, the regions of Picos de Europa and the Pyrenees. In particular, Pyrenees is an area with a historical tradition in artisanal cheesemaking, cheese being a cultural marker [4], and where dairy sector is a very important part of regional economies [6]. Within this context, "cheese consumption symbolizes a ritualistic, intimate sharing of a specialized quality food while simultaneously symbolizing the sharing of an ancient mountain culture" [33]. This is the case of Roncal valley analyzed in this research.

\section{Study method}

The objective of this paper is to analyze the opinion of cheese producers in Roncal valley with regard to the relationships between cheese and tourism. In particular, the objective of the interviews was to discover the key points in the process of awarding tourism value to cheese production and selling. Roncal valley is a municipality located on the north-eastern corner of Navarra region, northern Spain, in the border with France (Fig. 1) [34]. Roncal valley has a population of 1325 inhabitants [35] and it is formed by seven towns: Burgui, Vidángoz, Garde, Roncal, Urzainqui, Isaba, Uztárroz.

Data collection was carried out during a field trip to the Roncal valley between July 1 and July 5, 2019. This case study is based on a qualitative design which relies on semistructured interviews with local cheesemakers. Specifically, there are five local cheese producers located in the region. All of them were approached individually at their facilities but only three of the cheesemakers agreed to join the study. These three cheesemakers are those that also allow tourists' visits to their facilities, while the remaining two only perform as a selling point. On-site visits were conducted in the region to all the five local cheese producers who are the only producers allowed to make and distribute cheese under the PDO of Roncal cheese.

As part of the analysis of the responses of the interviewees, a process of codification and categorization was conducted by using a computer-assisted qualitative data analysis software (QDA Miner-Lite). As a result of data analysis, three themes were identified. Thus, results presented in the next section are divided into three sub- 


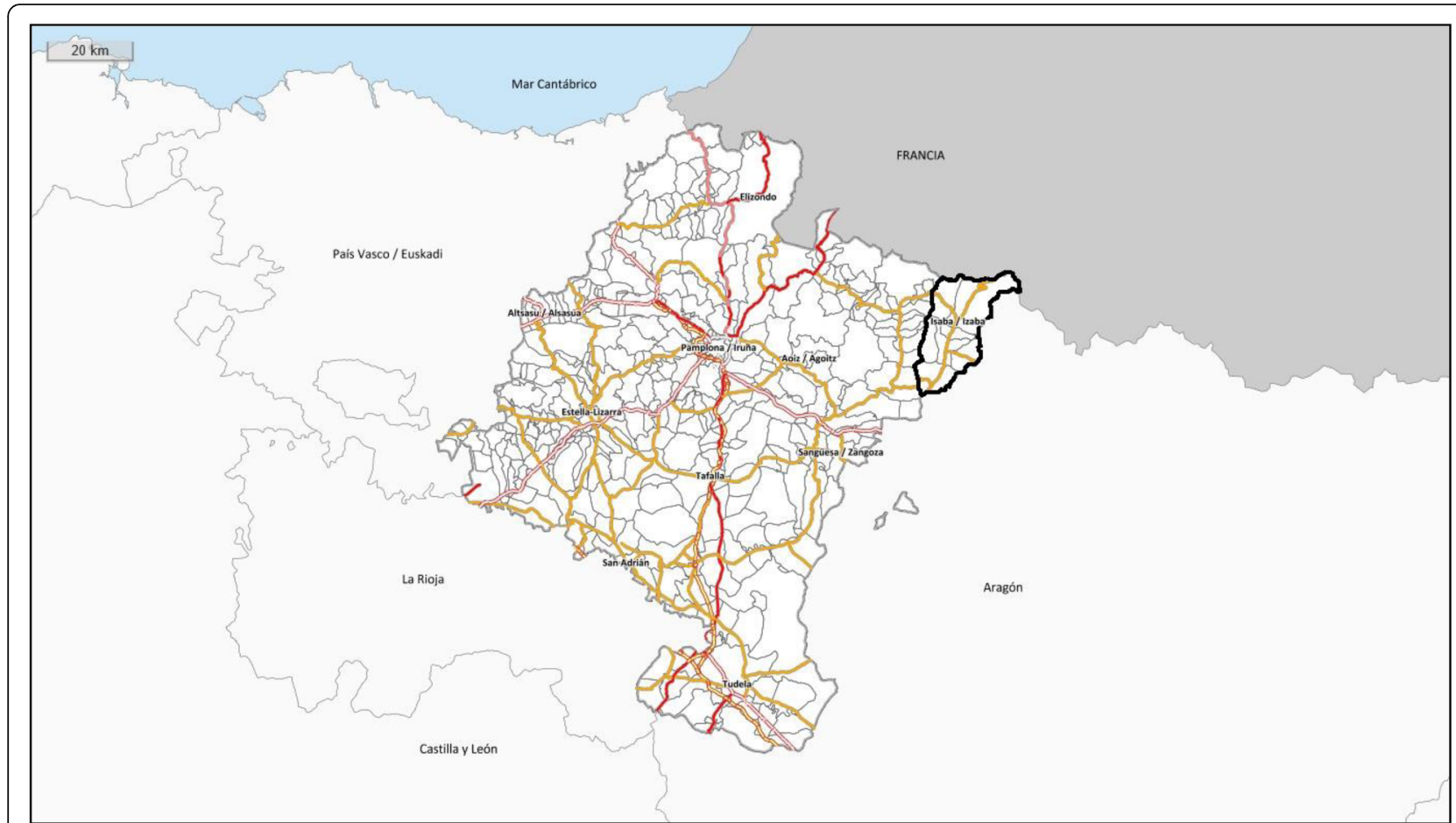

Fig. 1 Location map of the Roncal (Erronkari in Basque) valley. It is situated in the north-eastern corner of Navarra, in the Western Pyrenees, in a strategic location on the border between Spain and France (adapted from Infraestructura de Datos Espaciales de Navarra, 2020)

sections dealing with the predominant topics: landscape value of Roncal cheese, the rural lifestyle, and the cheese distribution and selling to visitors and tourists.

\section{Results}

The presentation of the results is divided into three parts, which were identified during the process of analysis, and are described below.

\section{The sense of place of Roncal cheese}

The most significant issue of cheese production, highlighted by all respondents, is the environment (see, for example, Fig. 2). Cheeses labeled with the PDO Roncal are made from "latxa" sheep milk, a local variety of sheep (Fig. 3)-grazing and feeding on Roncal landscapes. While cheesemaking is present over the history in the region, it was in the seventies of the twentieth century when a process of reappreciation of Roncal cheese started, as also explained in the following section. For example, one of the interviewees pointed out that they started to operate in 1984, with the aim of recovering the traditional shepherd cheese that had been lost. This interviewee stated that Roncal cheese has always been an exclusive cheese from Roncal valley. "Neither Salazar here in Navarra nor Ansó in Huesca as border areas and similar conditions have made this cheese". Cheesemaking in Roncal is a tradition that dates back to more than three thousand years ago-the Dolmen of
Arrako witnessed the process of making Roncal cheese: the remains of a shepherd's bag were found in there, with a hot stone that served to heat the milk to 30-32 ${ }^{\circ} \mathrm{C}$ in situ, representing the oldest origin of cheesemaking in the valley.

In this context, transhumance is very important as a tradition of preservation and appreciation of the landscape environment, which in turn is the main economic source of Roncal people: the economy of the valley is

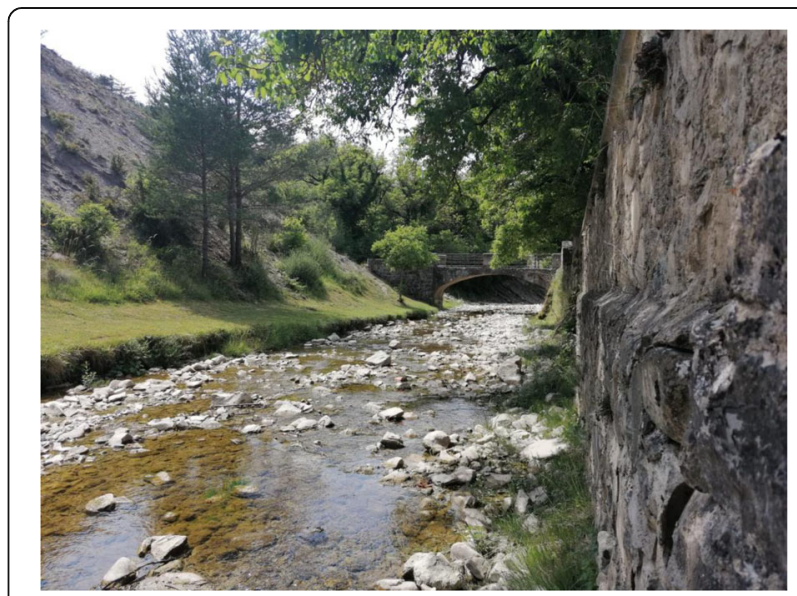

Fig. 2 A landscape in Roncal valley. The environment is a critical factor in food production. Specifically, cultural and natural values of local landscape are transferred to cheese (own source) 


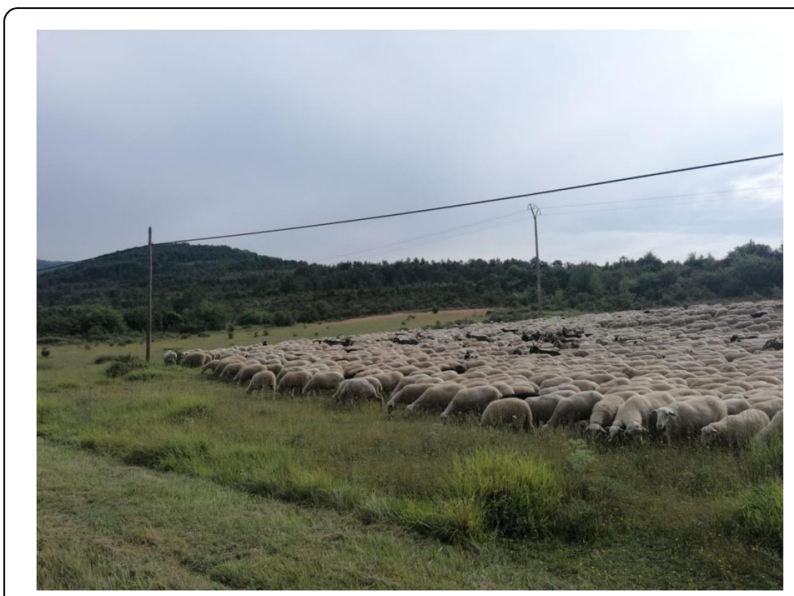

Fig. 3 Transhumance of "latxa" sheep in Roncal valley. "Latxa" sheep are native to the Basque Country and Navarra, and transhumance is an example of rural intangible heritage which relies on the appreciation and conservation of local landscapes (own source)

based on wood production and livestock (sheep), where tourism currently is aggregated, all the three respondents agreed. Thus, transhumance is a way of life in Roncal valley, and where the herds used to go from the area of Bardenas Reales (in winter) to Uztárroz (in summer), in the north of Roncal valley. Roncal was the first place to acquire the right to use the Bardenas Reales, granted by the King of Navarra. Another feature of this mountain valley is that all Roncal shepherds can graze on any public or private land in the valley, and the herds can "eat" anywhere. This guarantees the feeding of the animals whether or not the shepherds have their own lands. This rural way of life is also reflected in a "jota," a traditional folk dance, which says: "A las Bardenas Reales, Ya bajan los roncaleses, A comer migas con sebo, Por lo menos siete meses" (in English, "To the Bardenas Reales, Roncal people are going down, to eat migas con sebo [a traditional shepherd dish], at least seven months".

\section{Coping with the difficulty of rural life}

Cheese production suffered a decline in the midtwentieth century due to rural people emigrations to urban environments. In Roncal, in 1975, Enaquesa was created with the twofold aim to recover Roncal cheese production and to stop depopulation. Cheese is made with "latxa" sheep milk, as reported above. "It is necessary to milk seven sheep, twice a day, to make a kilogram of Roncal cheese". As mentioned earlier, in 1981 the protected designation of origin (PDO) of Roncal cheese was created, which was the first PDO awarded to a food product and the first PDO awarded to a cheese in Spain. Thus, cheeses under the PDO are made with raw milk from "latxa" sheep, available from
December to July. What does it mean? The interviewees highlighted that "latxa" sheep milk is scarce, which makes Roncal cheese an exclusive and unique product. Little by little, from the $80 \mathrm{~s}$ of the twentieth century, other cheese producers started to make Roncal cheese, known as Roncal shepherd cheese. During these decades, cheesemaking has been structuring an offer that currently counts on five producers: Larra, Ekia, and Onkizu, which allow on-site visits, and Borda Marengo and Enaquesa.

However, as one of the interviewees points out, the difficulty associated with rural life has never changed and makes it difficult, in turn, to ensure continuity of rural economy and the preservation of its cultural manifestations (see, for example, Fig. 4). "Young people prefer to work 8 hours in a factory, not countryside life. Few decades ago, everything was done by hand, and now farms are unproductive. Those working with animals is because they like it and it is often done as a hobby. Economically it is nothing. 365 days a year. This slavery is no longer wanted by anyone, not even those of twenty, thirty, forty years old". Traditionally, the life of a "pastor" (a shepherd) has been a very hard life, far from families, due to the transhumance. Currently, tourism also helps to cope with it. An example of conversion of "cheese product" to "cheese resource" is the Cheese Museum, opened in 1995 as part of Ekia cheese facilities. "We made a collection of materials from several people in the town, and when people see it, they get excited. Older local people cry because there are plenty of memories from old times. On the other hand, for young people there are many utensils that they do not know what they are" (Fig. 5). This exemplifies the role of the museum as a guarantor of the rural cheese tradition, valued and communicated to visitors and tourists as part of the

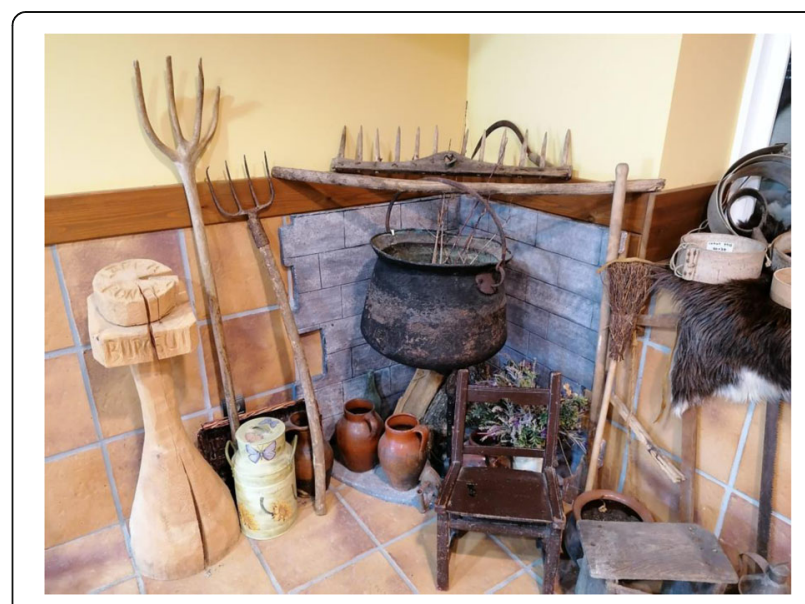

Fig. 4 Example of rural heritage. The production of cheese implies a series of processes from milking to ripening, which requires the use of a wide range of machinery and materials (own source) 


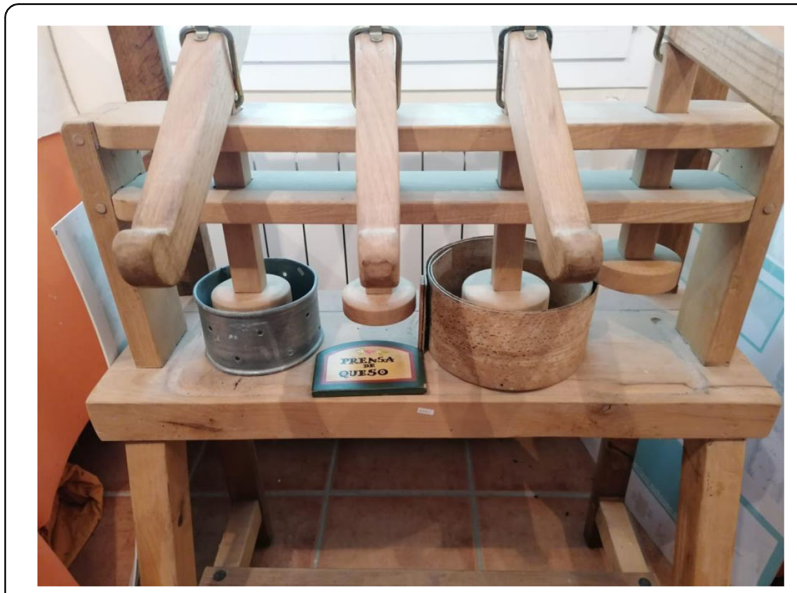

Fig. 5 Cheese press in the Cheese Museum. Food museums have not only emerged to preserved local heritages, but also to promote the sense of place to visitors and tourists. The museum offers a journey through shepherd culture not only via equipment and utensils, but also via photographs and documents (own source)

opportunities derived from cheese-oriented tourism practices.

\section{The distribution of cheese and the seasonality of tourist demand}

The main selling point of cheesemakers is the own facility, which also serves as a production area and a maturation cave (Fig. 6). However, it is important to acknowledge the selling through local agri-food stores, supermarkets (also regional chains), and distribution in municipalities in both Navarra (also in its capital city, Pamplona) as well as in neighboring provinces such as Huesca, in Aragón. In this context, participation in fairs and festivals and, mostly, sale to restaurants are identified as key factors in the relationship between local food production and tourism. One of the interviewees points out that "in Navarra, small food retail businesses do have Roncal cheese, but in restaurants it is a bit complicated because the point is that restaurants have Roncal cheese, but they don't say it. In a salad, why don't they put 'Roncal cheese salad'? In a lasagna, in desserts..." Added to this comment, the researcher has observed in restaurant menus that this is what really happens. Most of the restaurants offer cheese-based dishes, but they do not mention where it is from, and you can only confirm that it is Roncal cheese when you ask directly. Thus, only in some restaurants, it was possible to note, in dessert menus, dishes such as "Roncal Cheese" or "Cheese of the PDO Roncal, nuts and quince" (Fig. 7), with the consequent visibility given to the local product.

In relation to tourists, respondents agreed that tourist flows are predominantly concentrated in July and August, on weekends, and traditional Christmas and Easter holidays. Tourists come from both national markets (Aragón,

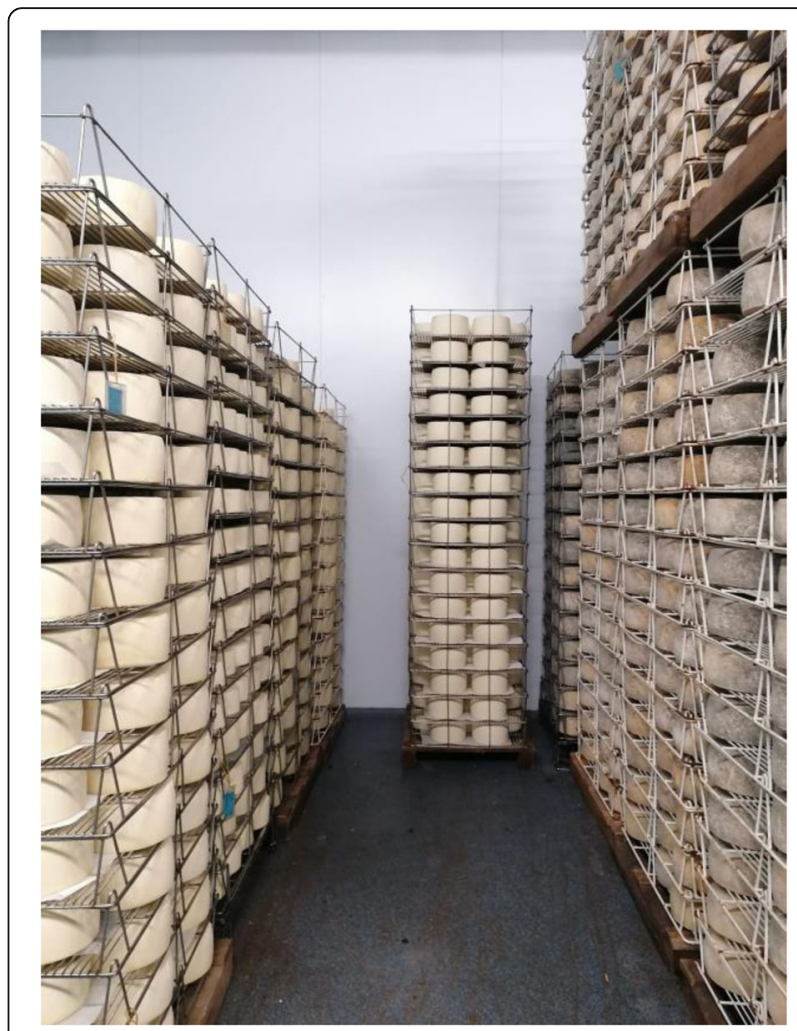

Fig. 6 Cheese maturation cave in Roncal valley. Cheese ripening is a crucial step in cheesemaking processes, which provides cheese with its ultimate flavor. Cheese caves are considered a tourist attraction (own source)

Catalunya, Valencia, and Madrid) and international markets, where tourists from France, The Netherlands, and the UK are highlighted. Also, as reported by one of the cheese producers, sales to tourists occur likewise in winter, from December to April, thanks to group tours, for example of senior tourists and schoolchildren. Although one of them emphasized that "performing visits is complicated because we are few people to do everything and the good thing is tourists see how the milk is processed and you have to leave your work to make the visit," another interviewee pointed out that guided tours are one of their main sources of income, especially because of cheese tastings and subsequent sales, where tourists purchase vacuum-packed cheeses as a souvenir.

\section{Discussion and conclusions}

This study develops an understanding of how agri-food producers in the northern Spanish region of Roncal perceive the processes of cheesemaking towards its current and potential relationship with tourism. Results revealed the key drivers of this relationship from the perspective of local cheese producers. This research identified three critical issues. The first one is the significance of the land, and the historical, cultural, and natural production 


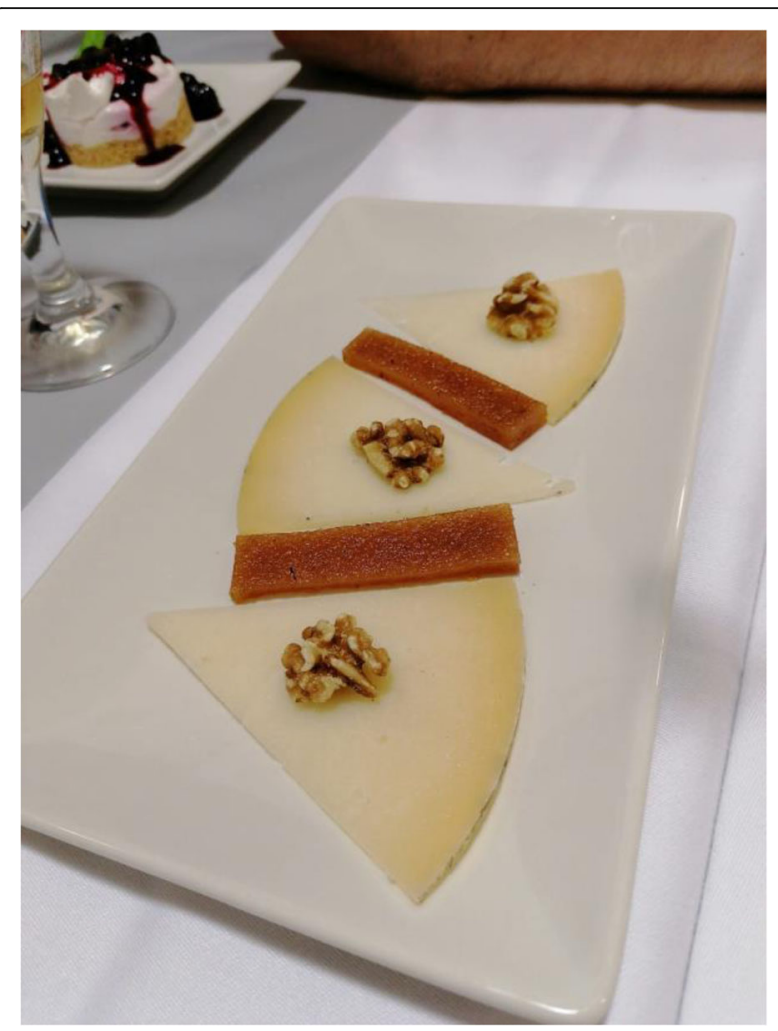

Fig. 7 Cheese dessert in a local restaurant. Restaurants are meaningful spaces where visitors and tourists can discover local foods and local recipes. This example of "Cheese of the PDO Roncal, nuts and quince" illustrates a combination of regional products as part of a local-based cuisine which accentuates the territorial development attached to tourism practices (own source)

and distribution processes associated with cheesemaking in rural and mountain areas such as the Pyrenees. These elements are both tangible and intangible inheritances which are primarily observed in transhumance as a modus vivendi of rural ways of life. It is this rural lifestyle, the second crucial factor. In particular, the quality of the environment where rurality happens and it is manifested through the protected designation of origin as a form to acknowledge the aforementioned sense of place, which is transferred to visitors and tourists through cheese-being this the third theme, that is, how cheesemakers are able to reach tourism demand.

This paper contributes to the emerging literature on cheese tourism as a specialist food tourism by understanding the producers' approach to the process of awarding tourism value to cheese. As previous research has studied, cheese tourism reflects a close relationship between food, land, and communities through localbased production [2]. Cheese tourism, as any other special interest tourism, can engage with the diversification of a destination's offer, while natural and cultural idiosyncrasies of the place are preserved, valorized, and promoted. To do this, it is obligatory to know what do producers think, in order to develop both a sustainable and mutually profitable relationship between agricultural and tourism industries.

Cheese as an example of food provided to visitors and tourists with the meanings attached to the local sense of place [36-38], its symbolic and unique geographical and cultural heritages [17]. Results of this study confirm what previous research has identified: "the quality of typical foods derives from a combination of human skill and knowledge, the character of the surrounding ecosystem, and the cultural appreciation of the interlinkages between these components" [15]. These meanings include how a landscape is and how it has evolved and continues changing. It also refers to meanings that showcase how Pyrenean culture and Pyrenean people has negotiated during centuries the processes of milk production and cheesemaking as part of their daily eating habits, the commercial exchange, and their tourism system. All of these concepts enhance the destination development and contribute to the understanding of the visited place [16]. Restaurants certainly emerge as a venue to "stage" it.

This paper offers an opportunity for further research where visitors and tourists to the Roncal valley are questioned about how they perceive the valley, and, specifically, about the role that cheese plays as both an attraction factor and as an ingredient of tourist experience (and post-experience). Another issue which requires further inquiry is the analysis of the online communication local cheesemakers are performing. As Rousseau [39] states, "new media platforms like blogs, webzines, Facebook and Twitter have opened up new spaces to talk about food, and virtual communities blossomed in a very short space of time through sharing recipes and stories across traditional boundaries of place". New technologies and globalization can provide local food producers with a tool to reduce geographical gaps between them and global consumers [40].

The main limitation of this research is the fact that it relies on the opinion of "only" three producers (nonetheless, they represent $60 \%$ of the cheesemakers settled in the area), and it is limited to a "small" location in the region of Navarra. While the relevance of this environment for milk and cheese production was early described, upcoming research could further analyze the stakeholders' opinion in other Spanish regions, in order to draw more robust perceptions about the relationships built between cheese and tourism sectors and identify differences and similarities. Cheese in places like Roncal valley is a genuine food, exclusive, and seasonal. Because cheese relies on the milk obtained from the animals whose feeding depends on the landscape-as a consequence, cheese has a different taste in each place and 
even over the year due to the season when it is made and according to the environmental conditions and the "taste" of the land. This is relevant for management and marketing purposes in terms of designing an "authentic" storytelling which is increasingly worth to experienceas Stanley and Stanley [41] point out, "one of the drivers of food tourism is nostalgia and a desire by tourists to rediscover the past" which is also manifested in cheese tourism [42].

\section{Acknowledgements}

The author would like to thank the availability of the participants in this study.

\section{Author's contributions}

The author designed, wrote, and revised the research, and approved the final version of the manuscript.

\section{Funding}

The field work of this research is made possible thanks to the financial support of the research unit LMRT (Laboratori Multidisciplinar de Recerca en Turisme), Faculty of Tourism, University of Girona.

\section{Availability of data and materials}

The analyzed data are incorporated in the research article.

\section{Competing interests}

The author declares that there are no competing interests.

Received: 6 February 2020 Accepted: 12 August 2020

Published online: 26 August 2020

\section{References}

1. Ermolaev VA, Yashalova NN, Ruban DA. Cheese as a tourism resource in Russia: the first report and relevance to sustainability. Sustainability. 2019; 11(19):5520.

2. Fusté-Forné F. Cheese tourism: local produce with protected designation of origin in the region of Galicia, Spain. In: Hall CM, Gössling S, editors. Food tourism and regional development: networks, products and trajectories. Abingdon, United Kingdom: Routledge; 2016. p. 242-52.

3. UNWTO. Guidelines for the development of gastronomy tourism. World Tourism Organization: Madrid, Spain; 2019.

4. Fusté-Forné F. Cheese tourism in a World Heritage site: Vall de Boí (Catalan Pyrenees). Eur J Tour Res. 2015;11:87-101.

5. Ministerio de Agricultura. Pesca y Alimentación. Catálogo Electrónico de Quesos de España. Ministerio de Agricultura, Pesca y Alimentación, Gobierno de España: Madrid, Spain; 2019.

6. Eurostat. Production of cheese. 2019. https://ec.europa.eu/eurostat/tgm/ table.do?tab=table\&plugin $=1 \&$ language $=$ en $\&$ pcode $=$ tag00040. Accessed 30 October 2019

7. Fusté-Forné F. Alimentación y Turismo: potencialidades de la elaboración de queso en España. CULTUR Revista de Cultura e Turismo. 2018;12(2):60-87.

8. Sanz Tolosana E. Identidad, montaña y desarrollo. Los valles de Roncal, Salazar y Aezkoa. Donostia-San Sebastián, Spain: Eusko Jaurlaritzaren Argitalpen Zerbitzu Nagusia, Servicio Central de Publicaciones del Gobierno Vasco; 2009.

9. Rachão $S$, Breda Z, Fernandes $C$, Joukes V. Food tourism and regional development: a systematic literature review. Eur J Tour Res. 2019;21:33-49.

10. Hall CM, Sharples L. The consumption of experiences or the experience of consumption? An introduction to the tourism of taste. In: Hall CM, Sharples L, Mitchell R, Macionis N, Cambourne B, editors. Food tourism around the world: development, management and markets. Oxford, United Kingdom: Butterworth Heinemann; 2003. p. 1-24.

11. Long LM. Learning to listen to the food voice: recipes as expressions of identity and carriers of memory. Food Cult Soc. 2004;7(1):118-22.

12. KPMG. La gastronomía en la economía española. KPMG International: Madrid, Spain; 2019.
13. Berno $T$, Laurin $U$, Maltezakis $G$. The special role of agriculture in food tourism. In: Wolf E, Lange-Faria W, editors. Have fork will travel: handbook for food tourism. Portland, United States: World Food Travel Association; 2014. p. $105-14$

14. Hall CM. Heirloom products in heritage places: farmers markets, local food, and food diversity. In: Timothy D, editor. Heritage cuisines: traditions, identities and tourism. Abingdon, United Kingdom: Routledge; 2016. p. 88-103.

15. Miele M, Murdoch J. The practical aesthetics of traditional cuisines: slow food in Tuscany. Sociologia Ruralis. 2002;42(4):312-28.

16. Andersson TD, Mossberg $L$, Therkelsen A. Food and tourism synergies: perspectives on consumption, production and destination development. Scandinavian Journal of Hospitality and Tourism. 2017;17:1-8.

17. Germann MJ. Eating difference: the cosmopolitan mobilities of culinary tourism. Space Cult. 2007:10(1):77-93.

18. Torquati B, Frascarelli A, Sylvander B, Barjolle D, Arfini F. Relationship between territory, enterprises, employment and professional skill in the typical products sector: an analysis in the Umbrian territory. In: Sylvander B, Barjolle D, Arfini F, editors. The socio-economics of origin labelled products: spatial, institutional and coordination aspects, proceedings of the $67^{\text {th }}$ EAAE Seminar. Le Mans, France: Eur Assoc Agric Econ; 1999. p. 341-57.

19. Walsh JA, Jamrozy U, Burr SW. Sense of place as a component of sustainable tourism marketing. In: McCool SF, Moisey RN, editors. Tourism, recreation and sustainability: linking culture and the environment. New York, United States: CABl; 2001. p. 195-216.

20. Fusté-Forné F, Berno T. Food tourism in New Zealand: Canterbury's foodscapes. Journal of Gastronomy and Tourism. 2016;2:71-86.

21. De Myttenaere B. Tourisme rural et valorisation des ressources alimentaires locales: Le cas de l'AOP fromage de Herve. Bulletin-Société géographique de Liège. 2011;57:37-51.

22. Medeiros MDL, da Cunha JAC, Passador JL. Gastronomic tourism and regional development: a study based on the minas artisanal cheese of Serro. Caderno Virtual de Turismo. 2018;18(2):168-89.

23. Dumas L, Menvielle W, Perreault JD, Pettigrew D. Terroirs, agrotourisme et marketing: le cas des fromages québécois. Téoros. Revue de recherche en tourisme. 2006;25(1):34-41.

24. Blanco M, Riveros $\mathrm{H}$. Las rutas alimentarias, herramienta para valorizar productos de las agroindustrias rurales. El caso de la ruta del queso Turrialba, Costa Rica. Perspectivas Rurales Nueva Época. 2005;17-18:85-97.

25. Gerz A, Dupont F. Comté cheese in France: impact of a geographical indication on rural development. Origin-based products: lessons for propoor market development. Bulletin. 2006;372:75-87.

26. Marcoz EM, Melewar TC, Dennis C. The value of region of origin, producer and protected designation of origin label for visitors and locals: the case of fontina cheese in Italy. International Journal of Tourism Research. 2016;18(3):236-50.

27. Thomé H, Vizcarra I, Espinoza A. Performancia y fractalización como herramientas de metabolización de los espacios rurales. El caso de la Ruta del Queso y el Vino de Querétaro'. Span J Rural Dev. 2015;6(1):29-44.

28. Berno T, Fusté-Forné F. Imaginaries of cheese: revisiting narratives of local produce in contemporary world. Annals of Leisure Research. 2019; aheadof-print: 1-20.

29. Soltani A. Cultural and touristic aspects of Gamalost, a local cheese from the Fjord of Norway. J Gastron Tour. 2019;3(4):271-81.

30. Folgado-Fernández JA, Di-Clemente E, Hernández-Mogollón JM. Food festivals and the development of sustainable destinations. The case of the cheese fair in Trujillo (Spain). Sustainability, 2019. 11(10):2922.

31. Grewe R. Llibre de Sent Soví: receptari de cuina. Barcino: Barcelona, Spain; 1979.

32. Michelson P. Los mejores quesos artesanos del mundo. Un recorrido por el sabor, la tradición y las regiones queseras. Blume: Barcelona, Spain; 2014.

33. Sidali KL, Kastenholz E, Bianchi R. Food tourism, niche markets and products in rural tourism: combining the intimacy model and the experience economy as a rural development strategy. J Sustain Tour. 2015;23(8-9):1179-97.

34. Infraestructura de Datos Espaciales de Navarra (IDENA). Geoportal de Navarra. 2020. https://idena.navarra.es/navegar [accessed on July 21, 2020].

35. Instituto Nacional de Estadística. Demografía y Población. 2019: retrieved from https://www.ine.es/dyngs/INEbase/es/categoria.htm?c=Estadistica P\&cid=1254734710984. Accessed 30 Oct 2019.

36. Cohen E, Avieli N. Food in tourism: attraction and impediment. Ann Tour Res. 2004;31(4):755-78. 
37. Mak AH, Lumbers M, Eves A. Globalisation and food consumption in tourism. Ann Tour Res. 2012;39(1):171-96.

38. Sims R. Food, place and authenticity: local food and the sustainable tourism experience. Journal of Sustainable Tourism. 2009;17:321-36.

39. Rousseau S. Food and social media: you are what you tweet. Plymouth, United Kingdom: Altamira Press; 2012.

40. Morton J. Time is $100 \%$ right to establish New Zealand as world leader in food-for-health. The New Zealand Herald. 2016: April 13.

41. Stanley J, Stanley L. Food tourism: a practical marketing guide. London, United Kingdom: CABl; 2014.

42. Fusté-Forné F. Savouring place: cheese as a food tourism destination landmark. Journal of Place Management and Development. 2020;13(2):177-94.

\section{Publisher's Note}

Springer Nature remains neutral with regard to jurisdictional claims in published maps and institutional affiliations.

Ready to submit your research? Choose BMC and benefit from:

- fast, convenient online submission

- thorough peer review by experienced researchers in your field

- rapid publication on acceptance

- support for research data, including large and complex data types

- gold Open Access which fosters wider collaboration and increased citations

- maximum visibility for your research: over $100 \mathrm{M}$ website views per year

At BMC, research is always in progress.

Learn more biomedcentral.com/submissions 